\title{
Establishing a Stable Anode-Electrolyte Interface in Mg Batteries by Electrolyte Additive
}

\author{
Zhenyou Li,* Thomas Diemant, Zhen Meng, Yanlei Xiu, Adam Reupert, Liping Wang, \\ Maximilian Fichtner, and Zhirong Zhao-Karger*
}

Cite This: ACS Appl. Mater. Interfaces 2021, 13, 33123-33132

Read Online

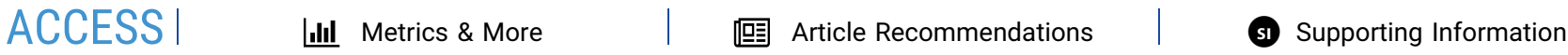

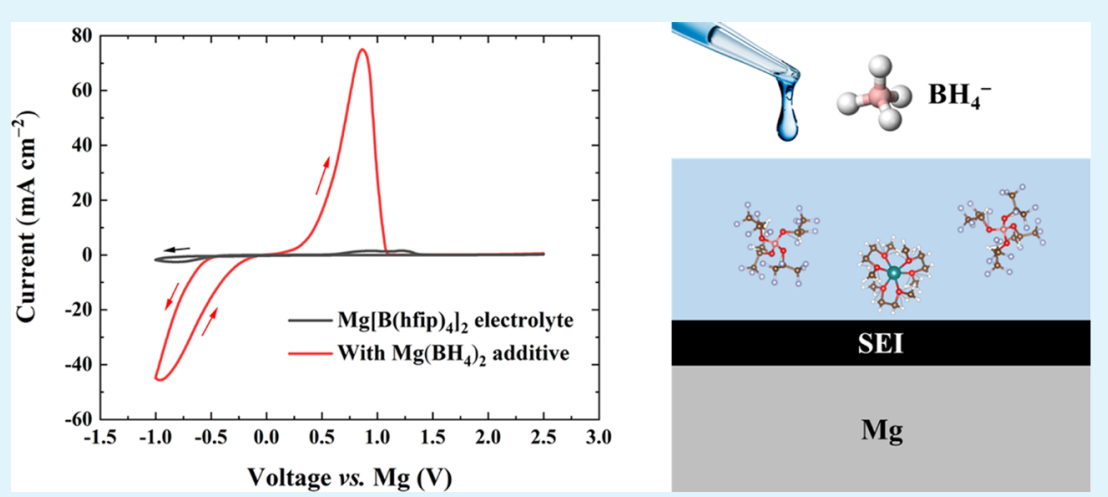

ABSTRACT: Simple magnesium salts with high electrochemical and chemical stability and adequate ionic conductivity represent a new-generation electrolyte for magnesium $(\mathrm{Mg})$ batteries. Similar to other $\mathrm{Mg}$ electrolytes, the simple-salt electrolyte also suffers from high charge-transfer resistance on the $\mathrm{Mg}$ surface due to the adsorbed species in the solution. In the current study, we built a model $\mathrm{Mg}$ cell system with the $\mathrm{Mg}\left[\mathrm{B}(\mathrm{hfip})_{4}\right]_{2} / \mathrm{DME}$ electrolyte and Chevrel phase $\mathrm{Mo}_{6} \mathrm{~S}_{8}$ cathode, to demonstrate the effect of such anode-electrolyte interfacial properties on the full-cell performance. It was found that the cell required additional activation cycles to achieve its maximal capacity. The activation process is mainly attributed to the conditioning of the anode-electrolyte interface, which could be boosted by introducing an additive amount of $\mathrm{Mg}\left(\mathrm{BH}_{4}\right)_{2}$ to the $\mathrm{Mg}\left[\mathrm{B}(\mathrm{hfip})_{4}\right]_{2} / \mathrm{DME}$ electrolyte. Electrochemical and spectroscopic analyses revealed that the $\mathrm{Mg}\left(\mathrm{BH}_{4}\right)_{2}$ additive helps to remove the native oxide layer and promotes the formation of a solid electrolyte interphase layer on $\mathrm{Mg}$. As a result, the full cell with the additive-containing electrolyte delivered a stable capacity from the second cycle onward. Further battery tests showed a reversible cycling for 600 cycles and an excellent rate capability, indicating good compatibility of the $\mathrm{Mg}\left(\mathrm{BH}_{4}\right)_{2}$ additive. The current study not only provides fundamental insights into the interfacial phenomena in $\mathrm{Mg}$ batteries but also highlights the facile tunability of the simple-salt $\mathrm{Mg}$ electrolytes.

KEYWORDS: Mg intercalation, noncorrosive electrolyte, electrolyte additive, electrode-electrolyte interfaces, Chevrel phase $\mathrm{Mo}_{6} \mathrm{~S}_{8}$

\section{INTRODUCTION}

Electrochemical deposits of magnesium $(\mathrm{Mg})$ from a nonaqueous electrolyte solution exhibit a more homogeneous morphology than the monovalent counterparts $(\mathrm{Li}$ and $\mathrm{Na}){ }^{1}$ allowing the implementation of the metallic $\mathrm{Mg}$ anode into the respective battery systems with less safety concern. The resulting rechargeable $\mathrm{Mg}$ batteries (RMBs) could theoretically promise solutions for high-energy-density devices in a costefficient and sustainable manner. ${ }^{2}$ With the development of the first prototype system, ${ }^{3}$ the $\mathrm{RMB}$ has the potential as an alternative and complementary strategy for the prevalent lithium-ion (Li-ion) technology.

However, transfer of results from the state-of-the-art $\mathrm{Li}$ based technology to the $\mathrm{Mg}$ systems is not straightforward, as battery chemistries involving divalent $\mathrm{Mg}$ ions are significantly different from the redox reactions that are based on the Li-ion shuttle. ${ }^{5}$ The bivalency and high charge density of $\mathrm{Mg}^{2+}$ ions induce a strong tendency to form ion pairs in liquid organic electrolytes, ${ }^{6,7}$ providing limited ionic conductivity and generating detrimental interfacial issues. ${ }^{8}$ In the electrolyte solution, there are competitions between solvent molecules and anions in coordination with $\mathrm{Mg}^{2+}$ ions. ${ }^{9}$ Approaches to sufficient cation-anion dissociation include either introducing auxiliary anions with larger association strength (e.g., chloride ions) ${ }^{10,11}$ or developing anions that interact weaker with $\mathrm{Mg}^{2+}$

Received: May 7, 2021

Accepted: June 23, 2021

Published: July 6, 2021 

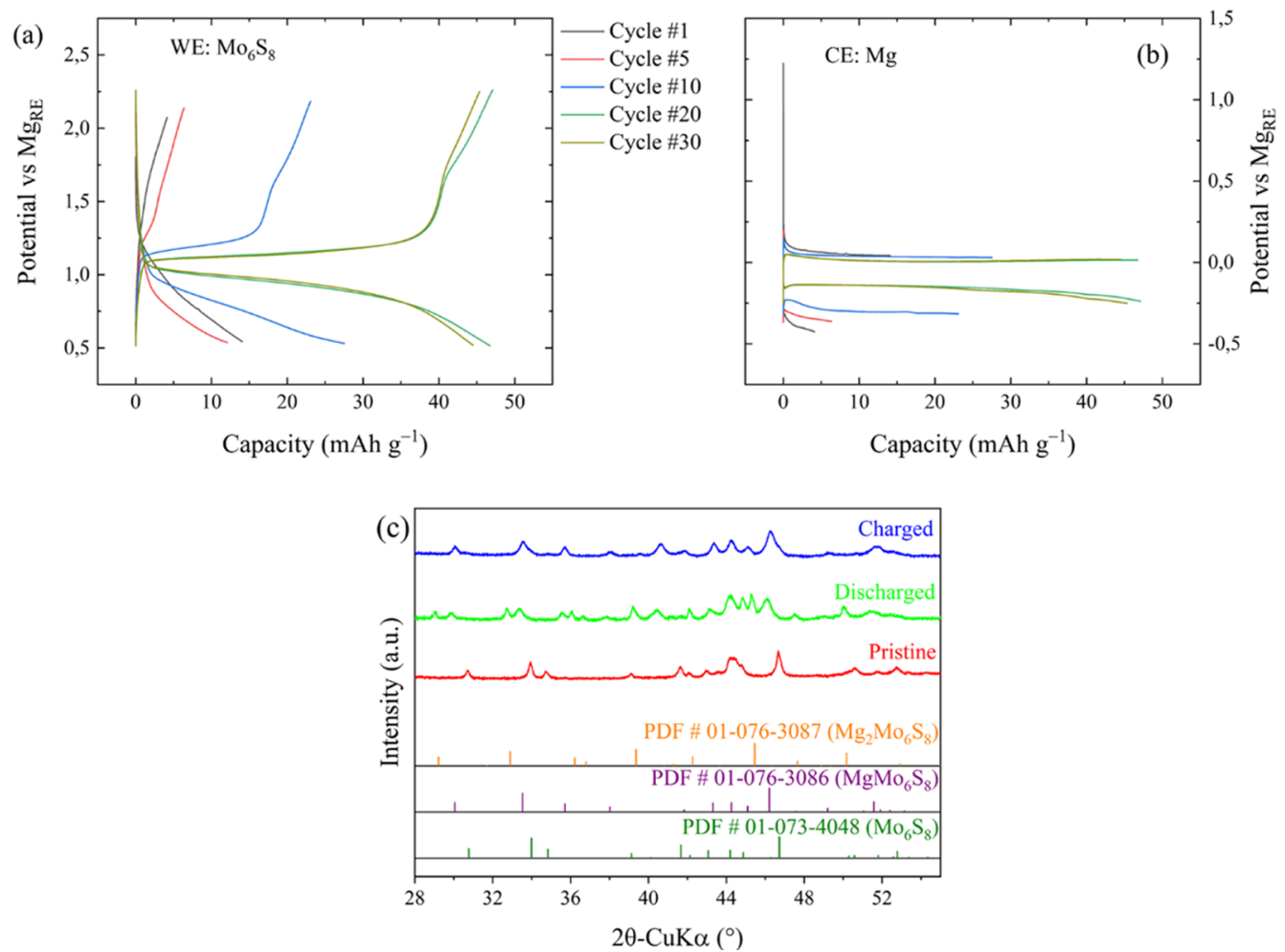

Figure 1. Galvanostatic cycling of a three-electrode cell comprising a $\mathrm{Mo}_{6} \mathrm{~S}_{8}$ working electrode $(\mathrm{WE})$, a $\mathrm{Mg}$ reference electrode (RE), and a $\mathrm{Mg}$ counter electrode (CE): voltage profiles of the $\mathrm{Mo}_{6} \mathrm{~S}_{8} \mathrm{WE}(\mathrm{a})$ and the $\mathrm{Mg} \mathrm{CE}$ (b). The cell was cycled at $50 \mathrm{~mA} \mathrm{~g}^{-1}$, with a $0.3 \mathrm{M} \mathrm{Mg}\left[\mathrm{B}(\mathrm{hfip}){ }_{4}\right]_{2} /$ DME electrolyte. (c) XRD patterns of the electrodes before and after cycling.

ions than the solvent molecules. ${ }^{12}$ The $\mathrm{Cl}^{-}$ions in the electrolyte were also identified as a multifunctional component and essential for interfacial charge transfer at the anodeelectrolyte interfaces. ${ }^{13,14}$ However, the corrosive nature of the Cl-based electrolytes limit their practical application. In contrast, the weak coordination concept enables simple ionic solution and exhibits high electrochemical stability and chemical compatibility, which are essential requirements for high-capacity conversion cathodes ${ }^{15,16}$ and high-voltage insertion cathodes, ${ }^{17}$ therefore representing advanced $\mathrm{Mg}$ electrolyte systems.

Despite the abovementioned excellent properties, this type of electrolyte also suffers from a growing anode impedance during open-circuit voltage (OCV), similar to other $\mathrm{Mg}$ electrolyte systems. ${ }^{18}$ The large impedance was correlated to some electrochemically inactive species in solution that tends to form an adsorption layer on the $\mathrm{Mg}$ surface, which hinders the mass transport and results in a huge voltage spike in the initial plating/stripping process. The adsorption layer gradually vanishes upon applying some voltage bias, and the overpotentials quickly drop to a small and stable value with a prolonged cycle in chronopotentiometry studies using symmetric cell configuration. ${ }^{19}$ However, overcoming such a huge energy barrier in the case of practical galvanostatic cycling with a limited voltage window may require a long conditioning process, leading to a misevaluation of the cathodes or the cell performance. The unique interfacial issue can be greatly mitigated by replacing the $\mathrm{Mg}$ metal anode with the $\mathrm{Mg}_{3} \mathrm{Bi}_{2}$ alloy, which shows drastic reduction of the anode impedance during $\mathrm{OCV}^{20}$ Similar improvement was observed when protecting the pristine $\mathrm{Mg}$ surface with a thin $\mathrm{MgF}_{2}$ layer $^{21}$ or an alloy-based interphase, ${ }^{22}$ implying that correct control of the interface is of considerable practical concern in $\mathrm{Mg}$ batteries.

In this study, we established a model system to demonstrate the impact of the abovementioned interfacial issue in a full cell, which contains the benchmarking Chevrel phase $\mathrm{Mo}_{6} \mathrm{~S}_{8}$ cathode, magnesium tetrakis(hexafluoroisopropyloxy)borate/ dimethoxyethane $\left(\mathrm{Mg}\left[\mathrm{B}(\mathrm{hfip})_{4}\right]_{2} / \mathrm{DME}\right)$ electrolyte and a $\mathrm{Mg}$ anode. It was found that reversible $\mathrm{Mg}$ de-/intercalation in the $\left.\mathrm{Mg}[\mathrm{B} \text { (hfip })_{4}\right]_{2} / \mathrm{DME}$ electrolyte is possible, but the cell requires some activation cycles. Further electrochemical analysis together with spectroscopic study attributed the activation process mainly to the conditioning of the anodeelectrolyte interfaces, in addition to some adjustment of the cathode structure. The activation can be alleviated by introducing magnesium borohydride $\mathrm{Mg}\left(\mathrm{BH}_{4}\right)_{2}$ as an electrolyte additive, which is beneficial for the removal of the native oxide layer and formation of a solid electrolyte interphase (SEI). By applying the $\mathrm{Mg}\left[\mathrm{B}(\mathrm{hfip})_{4}\right]_{2}$ electrolyte with an optimized $\mathrm{Mg}\left(\mathrm{BH}_{4}\right)_{2}$ additive concentration, the $\mathrm{Mo}_{6} \mathrm{~S}_{8}-\mathrm{Mg}$ cell provided an activation-free stable cycling for up to 600 times.

\section{RESULTS AND DISCUSSION}

2.1. $\mathrm{Mg}$ Intercalation into the $\mathrm{Mo}_{6} \mathrm{~S}_{8}$ Cathode from a $\mathrm{Mg}[\mathrm{B} \text { (hfip) }]_{2}$ /DME Electrolyte. $\mathrm{Mg}$ storage in the $\mathrm{Mo}_{6} \mathrm{~S}_{8}$ cathode seems highly dependent on the chloride-based electrolyte systems, in which the $\mathrm{Cl}^{-}$ions play decisive roles in the electrode-electrolyte interfaces at both anode and cathode sides. $^{13,23}$ So far, the combination of the $\mathrm{Mg}[\mathrm{B}$ (hfip) $\left.{ }_{4}\right]_{2}$ /DME electrolyte with the insertion cathode was only investigated with either a special cathode $\operatorname{design}^{24}$ or a novel intercalation chemistry. ${ }^{25}$ To validate the feasibility of the 

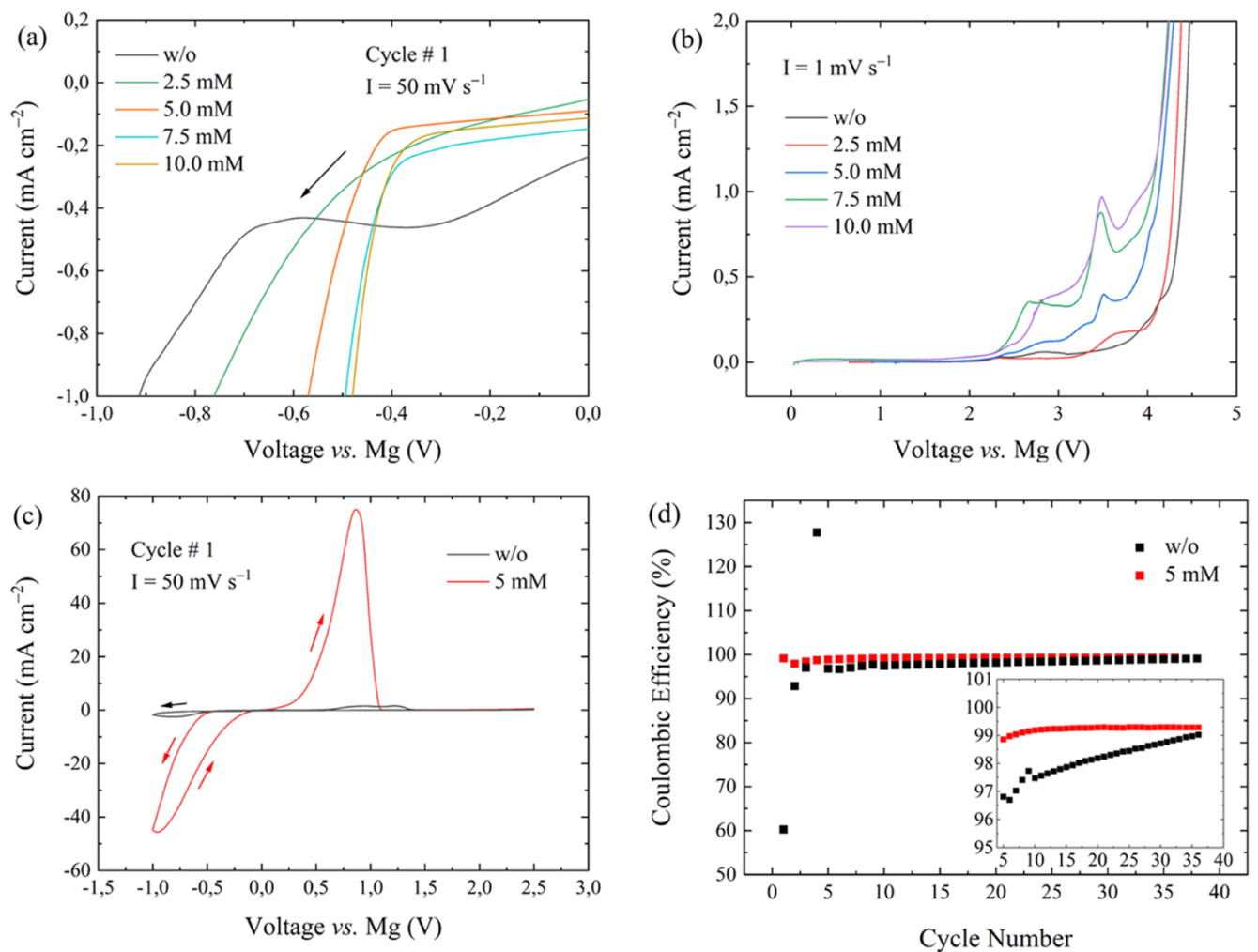

Figure 2. Electrochemical tests of the $0.3 \mathrm{M} \mathrm{Mg}\left[\mathrm{B}(\mathrm{hfip})_{4}\right]_{2} / \mathrm{DME}$ electrolytes with and without the $\mathrm{Mg}\left(\mathrm{BH}_{4}\right)_{2}$ additive: (a) initial $\mathrm{Mg}$ plating in the first cycle CV scan; (b) LSV of the electrolytes with various additive concentrations; (c) comparison of the first cycle CV with the neat electrolyte and with $5 \mathrm{mM} \mathrm{Mg}\left(\mathrm{BH}_{4}\right)_{2} ;$ (d) Coulombic efficiency of $\mathrm{Mg}$ plating/stripping using the neat electrolyte and with $5 \mathrm{mM} \mathrm{Mg}\left(\mathrm{BH}_{4}\right)_{2}$. $\mathrm{Pt}$ was used as the WE in all the CV and LSV measurements.

model system, $\mathrm{Mg}$ intercalation into the $\mathrm{Mo}_{6} \mathrm{~S}_{8}$ cathode was first studied by means of galvanostatic cycling in a threeelectrode cell. In order to mimic the two-electrode condition in the later sections, the applied voltage window of the threeelectrode cell was set to $0.5-2.5 \mathrm{~V}$ versus $\mathrm{Mg}_{\mathrm{CE}}$. Figure $1 \mathrm{a}$ shows the voltage profiles of the $\mathrm{Mo}_{6} \mathrm{~S}_{8}$ cathode versus $\mathrm{Mg}_{\mathrm{RE}}$ upon cycling, from which an increase in the capacity in the first 20 cycles was observed. The capacity increase is partially related to an activation process at the cathode side, as indicated by a simultaneous decrease in the charge-discharge overpotentials with more and more prominent voltage plateaus. According to a previous study, diffusion kinetics increases with the increase in $\mathrm{Mg}$ content in the $\mathrm{Mo}_{6} \mathrm{~S}_{8}$ lattice. $^{26}$ Therefore, a possible reason for the evolution of the charge-discharge curves could be some structural adjustment of the cathode host, which improves further Mg-ion mobility.

Nevertheless, the capacity stabilized at $\sim 48 \mathrm{~mA} \mathrm{~h} \mathrm{~g}^{-1}$ after the activation cycles, with a discharge plateau at $\sim 1.0 \mathrm{~V}$ and a voltage hysteresis of $\sim 0.2 \mathrm{~V}$. To clarify the de-/magnesiation process, electrodes at various states of charge were investigated by X-ray diffraction (XRD). As shown in Figure 1c, the pattern for the discharged sample can be indexed as a mixture of $\mathrm{MgMo}_{6} \mathrm{~S}_{8}$ and $\mathrm{Mg}_{2} \mathrm{Mo}_{6} \mathrm{~S}_{8}$, while the diffraction of the charged sample results in a pure $\mathrm{MgMo}_{6} \mathrm{~S}_{8}$ phase. $^{27}$ The XRD data demonstrate that the $\left.\mathrm{Mg}[\mathrm{B} \text { (hfip })_{4}\right]_{2} / \mathrm{DME}$ electrolyte supports $\mathrm{Mg}$ de-/intercalation in $\mathrm{Mo}_{6} \mathrm{~S}_{8}$, even at a high current of 50 $\mathrm{mA} \mathrm{g} \mathrm{g}^{-1}(\sim 0.4 \mathrm{C})$. The trapping of $\mathrm{Mg}$ in the $\mathrm{Mg}_{x} \mathrm{Mo}_{6} \mathrm{~S}_{8}$ structure may result from a slow diffusion kinetics at a low $\mathrm{Mg}$ content $(x<1)$, when $\mathrm{Mg}$ ions only occupy the inner rings of the cage. ${ }^{26}$ This also explains the respective voltage profile
(Figure 1a), where the higher discharge plateau at $\sim 1.2 \mathrm{~V}$ is missing.

In addition to the cathode contribution, $\mathrm{Mg}$ plating/ stripping at the anode side could be the main reason for the activation process. As shown in Figure $1 \mathrm{~b}$, the $\mathrm{Mg}$ stripping process requires initially a very large overpotential of $1.22 \mathrm{~V}$. A similar voltage spike was observed in our previous study with a $\mathrm{Mg}-\mathrm{Mg}$ symmetric cell using the same electrolyte and could be attributed to electrochemically inactive species adsorbed on the $\mathrm{Mg}$ surface that generate a large charge transfer impedance. ${ }^{19}$ The voltage spikes still appeared but quickly vanished in the subsequent cycles. In each cycle, the stripping voltage drops to $<0.1 \mathrm{~V}$ immediately after operating the cell, and the value is further reduced to $0.01 \mathrm{~V}$ after 20 cycles. In contrast, the respective plating processes suffer from more pronounced and persistent overpotentials of $-0.43 \mathrm{~V}$ in the first cycle, which decreases to $-0.15 \mathrm{~V}$ in the 20th cycle. The large overpotentials for $\mathrm{Mg}$ plating in the initial cycles reflect the sluggish charge transfer at the anode side, which could be related to the native oxide layer on fresh $\mathrm{Mg}$ foil. This intrinsic layer may impede the de-/magnesiation process at the cathode side and contributes to the overall charge-discharge overpotentials of the full cell (see Figure $\mathrm{S} 1$ ).

2.2. $\mathrm{Mg}\left(\mathrm{BH}_{4}\right)_{2}$ as an Additive to the $\mathrm{Mg}\left[\mathrm{B}(\mathrm{hfip})_{4}\right]_{2} /$ DME Electrolyte. In order to alleviate the activation process, $\mathrm{Mg}\left(\mathrm{BH}_{4}\right)_{2}$ was introduced as an electrolyte additive, with concentrations ranging from 2.5 to $10 \mathrm{mM}$, in the $0.3 \mathrm{M}$ $\mathrm{Mg}\left[\mathrm{B}(\mathrm{hfip})_{4}\right]_{2} / \mathrm{DME}$ electrolyte. Cyclic voltammetry (CV) experiments of a $\mathrm{Mg}-\mathrm{Pt}$ cell in Figure 2a showed a significant reduction of the overpotential related to $\mathrm{Mg}$ plating in the first cycle with the additive-containing electrolyte. At an onset 

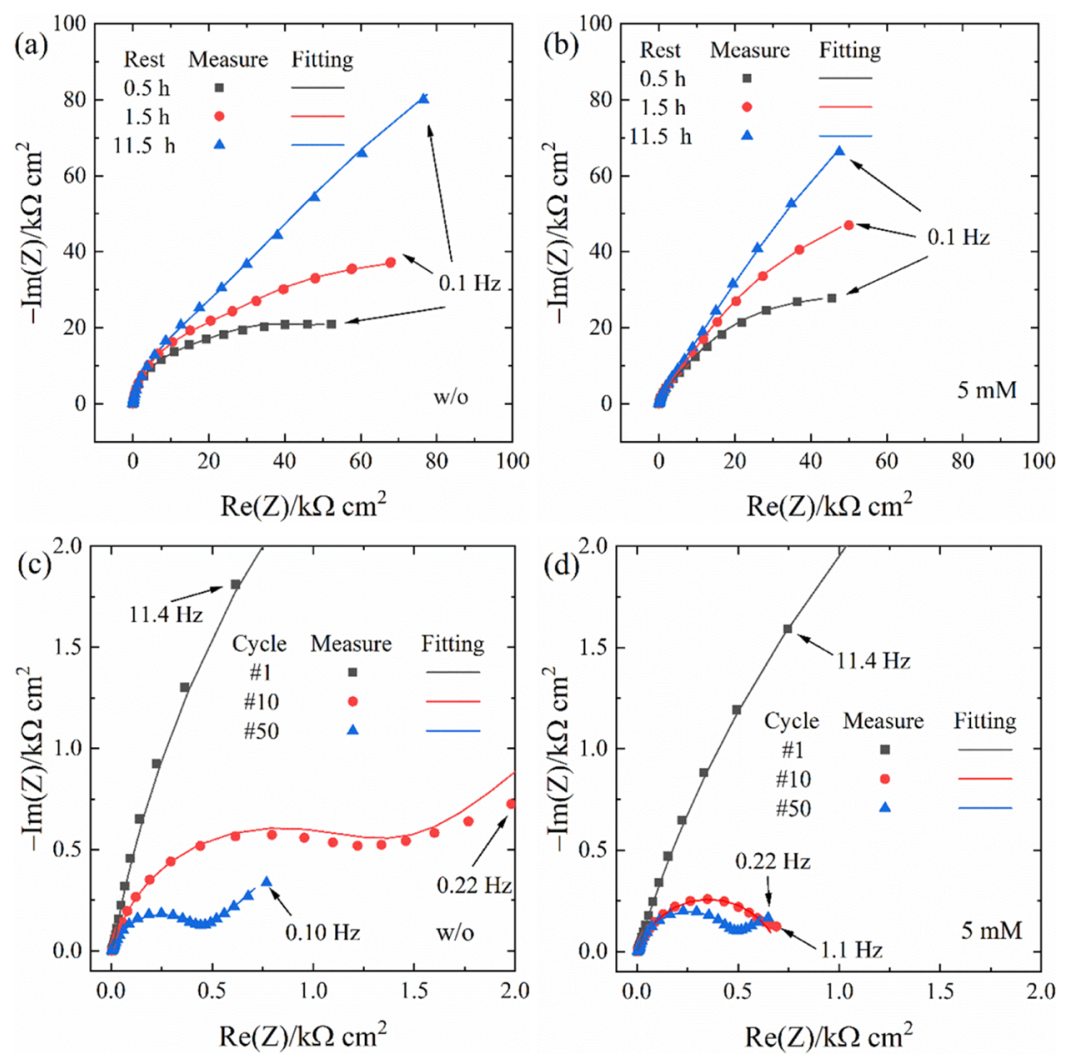

Figure 3. EIS of $\mathrm{Mg}-\mathrm{Mg}$ symmetric cells after resting in the (a) neat electrolyte or (b) electrolyte with a $5 \mathrm{mM}$ additive and upon cycling in the (c) neat electrolyte or (d) electrolyte with a $5 \mathrm{mM}$ additive.

current of $-0.6 \mathrm{~mA} \mathrm{~cm}{ }^{-2}$, a relatively high overpotential of $-0.76 \mathrm{~V}$ was received for the neat $\mathrm{Mg}\left[\mathrm{B}(\mathrm{hfip})_{4}\right]_{2} / \mathrm{DME}$ electrolyte, which is ascribed to the native oxide layer of the $\mathrm{Mg}$ foil and the adsorption species at the interfaces that impede Mg-ion mobility. ${ }^{18,19}$ With an increasing amount of $\operatorname{Mg}\left(\mathrm{BH}_{4}\right)_{2}$, the initial plating overpotential gradually decreased to $-0.63 \mathrm{~V}(2.5 \mathrm{mM}),-0.52 \mathrm{~V}(5 \mathrm{mM})$, and $-0.46 \mathrm{~V}(7.5$ $\mathrm{mM})$. A further increase in the $\mathrm{Mg}\left(\mathrm{BH}_{4}\right)_{2}$ concentration did not change the value any more $(-0.45 \mathrm{~V}$ for $10 \mathrm{mM})$.

It should be mentioned that $\mathrm{Mg}\left(\mathrm{BH}_{4}\right)_{2}$ provides a notably narrow electrochemical window, ${ }^{28}$ which limits its application as a bulk electrolyte salt to certain electrode couples. Therefore, the effect of the additive on the electrochemical window of the electrolyte was investigated by linear sweep voltammetry (LSV). In the case of the neat electrolyte (Figure $2 \mathrm{~b}$ ), no obvious current was measured for up to $4.0 \mathrm{~V}$ at a scan rate of $1 \mathrm{mV} \mathrm{s}^{-1}$. The oxidative stability of the neat electrolyte is beyond the limit of DME, which might be due to some passivation layers on the surface of the WE which suppress the DME decomposition. ${ }^{29}$ In contrast, new oxidation peaks start to form at lower voltages after the addition of $\mathrm{Mg}\left(\mathrm{BH}_{4}\right)_{2}$ to the electrolyte solution. With an additive concentration of $2.5 \mathrm{mM}$, a broad peak occurs at around $3.5 \mathrm{~V}$, which originates from the decomposition of the solvent, that is, DME. ${ }^{12}$ Emergence of the peak related to DME oxidation might be due to some pitting corrosion of the WE in the presence of $\mathrm{BH}_{4}^{-}$(or $\left[\mathrm{B}(\mathrm{hfip})_{4}\right]^{-}$anions). Therefore, the surface of the WE was activated for the decomposition of the solvent. When the $\mathrm{Mg}\left(\mathrm{BH}_{4}\right)_{2}$ concentration was increased to $5 \mathrm{mM}$, an additional oxidation peak related to the decomposition of $\mathrm{BH}_{4}{ }^{-}$at $\sim 2.5 \mathrm{~V}$ appeared. ${ }^{28}$ Further increasing the concentration of $\mathrm{Mg}\left(\mathrm{BH}_{4}\right)_{2}$ leads to more prominent peaks for the oxidation of $\mathrm{BH}_{4}{ }^{-}$and DME, resulting in a reduced electrochemical window.

Considering both the initial overpotentials for $\mathrm{Mg}$ plating and the anodic stability, the electrolyte with $5 \mathrm{mM} \mathrm{Mg}\left(\mathrm{BH}_{4}\right)_{2}$ was selected for further study. Due to the reduced overpotentials, the current response for $\mathrm{Mg}$ plating/stripping in the first cycle from the electrolyte with $5 \mathrm{mM} \mathrm{Mg}\left(\mathrm{BH}_{4}\right)_{2}$ is much more prominent than that from the neat electrolyte, as shown in Figure 2c. Furthermore, the CV curves of the electrolyte with the additive are almost overlapping in the following cycles (see Figure S2), suggesting a reversible and conditioning-free redox process on the $\mathrm{Pt}$ electrode. In comparison, $\mathrm{Mg}$ plating/ stripping from the neat electrolyte suffers from a conditioning process as reported in a previous study. ${ }^{15}$ The reversibility of $\mathrm{Mg}$ plating/stripping was further examined by the Coulombic efficiency (CE) determined from the $\mathrm{CV}$ measurement. As presented in Figure 2d, a stable CE value of $\sim 99.3 \%$ was received for the additive-contained electrolyte, while the $\mathrm{CE}$ values for the neat electrolyte showed instability in the first 10 cycles before constantly increasing from 97.5 to $99 \%$.

To clarify the origin of the plating/stripping overpotentials, chronopotentiometry of $\mathrm{Mg}-\mathrm{Mg}$ symmetric cells was performed, during which electrochemical impedance spectra (EIS) were recorded under both electrochemical static and dynamic conditions. Figure S3 shows the voltage profiles of the symmetric cells with a neat electrolyte (red) and the additivemodified electrolyte $\left[5 \mathrm{mM} \mathrm{Mg}\left(\mathrm{BH}_{4}\right)_{2}\right.$, green]. With the neat electrolyte, the cell exhibits an initial overpotential of $-0.52 \mathrm{~V}$ (Figure S3b), which decreases gradually during the plating process. The development of the voltage profile can be explained by a gradual activation of the electrode, possibly due to the removal of the native oxide layer at the counter $\mathrm{Mg}$ 

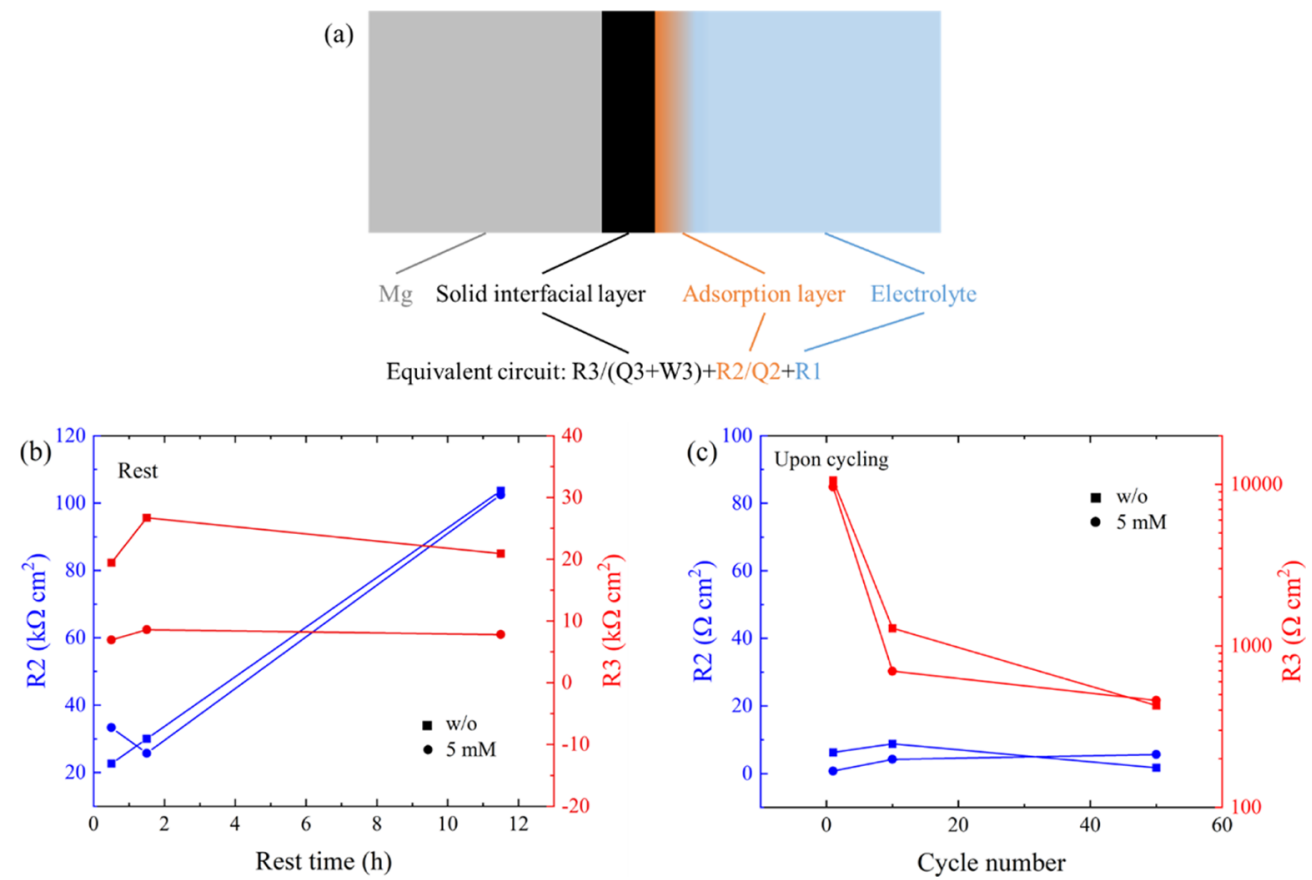

Figure 4. Equivalent circuit used for the fitting of the EIS results (a). Solid interfacial layer refers to a native oxide layer on Mg foil under static conditions, while it corresponds to a newly formed SEI layer under dynamic conditions. Development of impedance related to the adsorption layer (R2) and solid passivation layer (R3) during the rest time (b) and upon cycling (c).

electrode and/or building-up of a new interphase. In comparison, the cell with the additive-containing electrolyte shows a plating plateau at $-0.20 \mathrm{~V}$ with an onset value of $-0.35 \mathrm{~V}$, suggesting a kinetically more favorable and more homogeneous plating process. Upon further cycling (see Figure S3a), the plating overpotentials of the cells remained stable at around $-0.10 \mathrm{~V}$ for both electrolytes, but the additivecontaining electrolyte requires less conditioning cycles before reaching the stable state.

The symmetric cells were further tested after letting them rest for $10 \mathrm{~h}$ after every 50 cycles, in order to check the influence of the adsorption layer on the continuous switch between "on" and "off" states of a battery. As shown in Figure S4, there is always an overpotential spike noted after every resting period, suggesting a long-term effect. However, due to the conditioning of the $\mathrm{Mg}$ surface, the following spikes are only in the range of $0.1-0.2 \mathrm{~V}$, which is much smaller than the first one.

According to previous studies, ${ }^{18,19}$ the high impedance in the initial $\mathrm{Mg}$ plating process is mainly related to an electrochemically inactive adsorption layer on the electrode surface. When monitoring the process by EIS, a growth of the impedance value during the rest time was observed for both electrolytes (Figure 3a,b). Additionally, we speculate that the native oxide layer on the $\mathrm{Mg}$ surface also contributes to the overpotentials. Therefore, a model that considers the abovementioned processes (see Figure 4a) has been applied to fit the experimental EIS data. In particular, variations of the charge transfer resistances that originated from the adsorption layer (R2) and the solid interfacial layer (R3) are highlighted in Figure $4 \mathrm{~b}$. After $0.5 \mathrm{~h}$ rest, R2 and R3 contributed almost equally to the total impedance. However, R2 increased rapidly and exceeded $100 \mathrm{k} \Omega \mathrm{cm}^{2}$ after a rest time of $11.5 \mathrm{~h}$, which suggests a growth of the adsorption layer under static conditions. In comparison, the change in R3 over time was negligible, indicating a good chemical compatibility between both electrolytes and the $\mathrm{Mg}$ anode. The addition of the $\mathrm{Mg}\left(\mathrm{BH}_{4}\right)_{2}$ additive leads to a significant decrease in $\mathrm{R} 3$. This is probably due to a preferential adsorption of the reductive $\mathrm{BH}_{4}^{-}$at the interfaces, which is beneficial for removing the thin oxide layer on the fresh $\mathrm{Mg}$ anode and thus leading to a lower initial plating overpotential.

Upon cycling, the cell impedance decreased rapidly, as shown in Figure 3c,d. A simultaneous change in voltage hysteresis reveals their correlations (cif. Figure S3). The same equivalent circuit, as shown in Figure 4a, was applied to understand the interfacial charge transfer processes. R2 still represents the impedance induced by the adsorption layer, and R3 shows the impedance of the interphase layer including the remaining oxide layer and the formed SEI. Fitting the EIS data results in a sharp drop of $\mathrm{R} 2$ to a neglectable value upon cycling (Figure 4c), which is most probably due to the breakup of the adsorption layer under voltage bias and upon ion shuttling. The impedance related to the adsorption layer did not show a significant difference in both electrolytes, which could indicate that the additive amount of $\mathrm{Mg}\left(\mathrm{BH}_{4}\right)_{2}$ would not change the evolution of the adsorption layer. In contrast, there is a gradual change in the impedance related to the solid surface layer (R3) with respect to the cycle number, indicating a conditioning of the intrinsic thin film on the $\mathrm{Mg}$ surface. Nevertheless, the cell with the additive-containing electrolyte exhibits fewer conditioning cycles than the one with the neat electrolyte. After 10 cycles, the R3 value in the former case is only half of that in the latter case $\left(696 \Omega \mathrm{cm}^{2}\right.$ vs $\left.1284 \Omega \mathrm{cm}^{2}\right)$. Afterward, R3 gets fairly stable in the additive-contained electrolyte. Moreover, after 50 cycles, the R3 values are close to each other for both electrolytes $\left(460 \Omega \mathrm{cm}^{2}\right.$ vs $\left.427 \Omega \mathrm{cm}^{2}\right)$. The rapid change in $\mathrm{R} 3$ can be attributed to the higher reactivity of $\mathrm{BH}_{4}^{-}$and its higher association strength that promote the interfacial charge transfer by facilitating the 

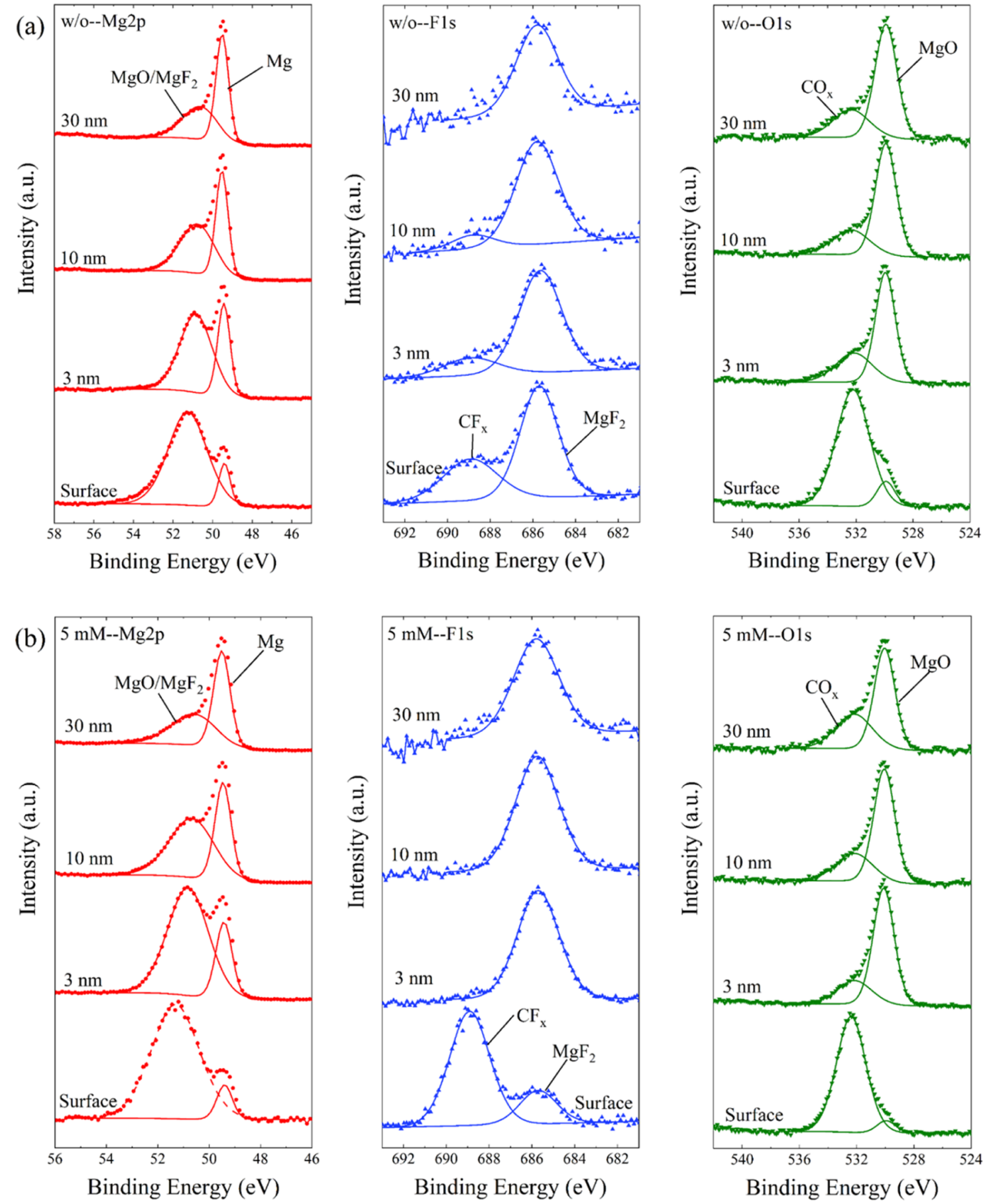

Figure 5. XPS spectra of Mg anodes cycled with the (a) neat electrolyte and (b) additive-containing electrolyte at selected depths.

formation of the SEI. ${ }^{10}$ The result demonstrated that a small amount of $\mathrm{Mg}\left(\mathrm{BH}_{4}\right)_{2}$ additive is enough to modify the interfacial properties.

To gain more insights into the composition of the interfacial layers on the $\mathrm{Mg}$ anodes, $\mathrm{X}$-ray photoelectron spectroscopy (XPS) measurements were carried out. XPS measurements were also collected after $\mathrm{Ar}^{+}$ion sputter treatment (for 3, 10,

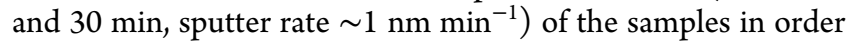
to create a depth profile. Figure S5 compares the development of the elemental concentrations with increasing depth of $\mathrm{Mg}$ anodes after initial cycles with the neat electrolyte or additivecontaining electrolyte. In both cases, a significant amount of non-Mg metal components was detected on the topmost surface, indicating the formation of an SEI layer after cycling. Furthermore, the semiquantitative analysis shows a similar trend in both electrolytes with increasing layer depth: a simultaneous reduction of the $\mathrm{C}, \mathrm{O}, \mathrm{F}$, and $\mathrm{B}$ concentrations goes along with an increase in $\mathrm{Mg}$ content within the surface region of the $\mathrm{Mg}$ anodes. The development of the interfacial compositions suggests that the thickness of the SEI layer was only limited to $\sim 10 \mathrm{~nm}$. Compared to the $\mathrm{Mg}$ anode cycled with the neat electrolyte, the one cycled with the additivecontaining electrolyte has a lower $\mathrm{Mg}$ content but higher content of the other elements at all measured depths, suggesting a slightly thicker SEI. 

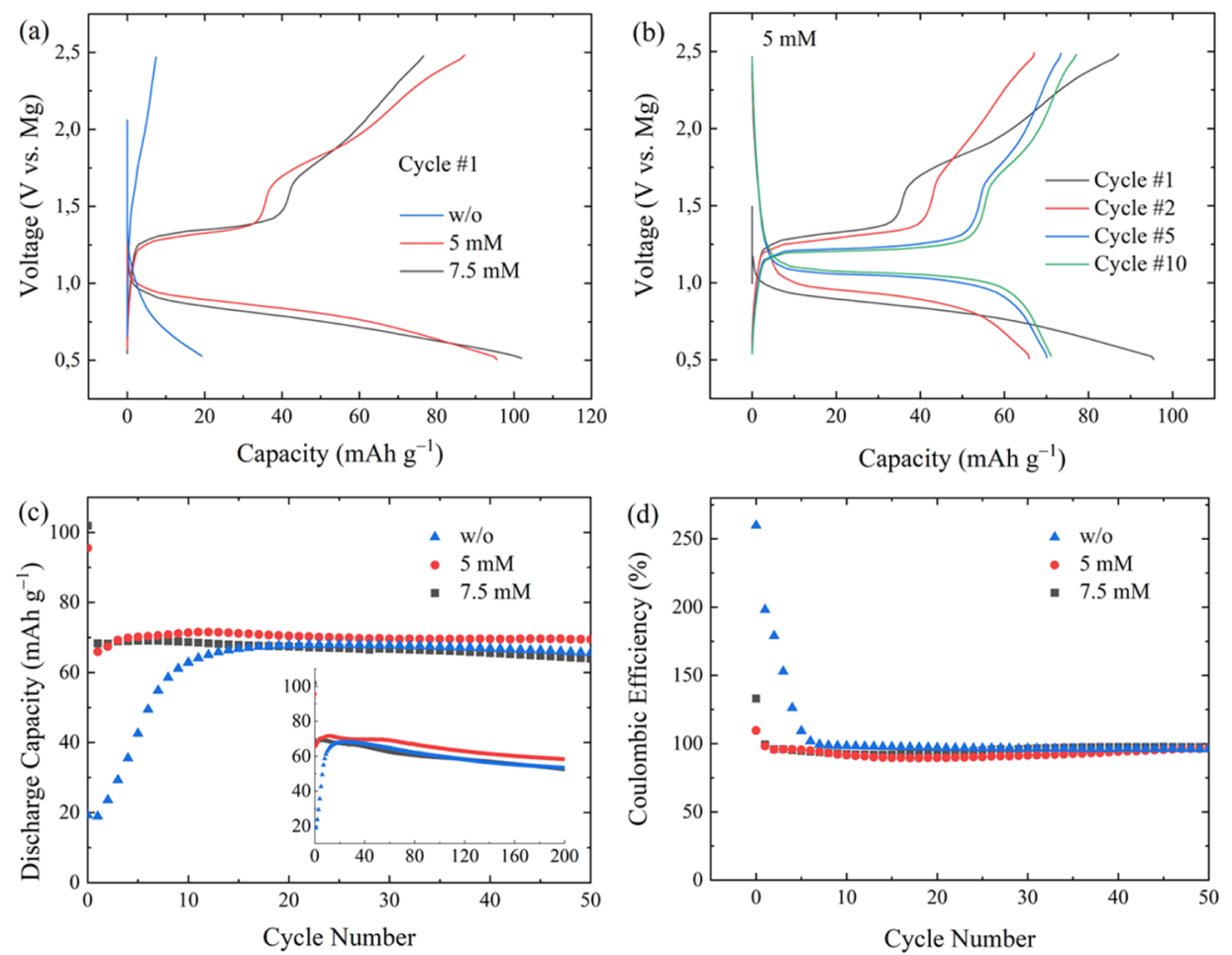

Figure 6. (a) Initial voltage profiles of the cell with the $\mathrm{Mg}\left[\mathrm{B}(\mathrm{hfip})_{4}\right]_{2} / \mathrm{DME}$-based electrolyte. (b) Voltage profiles of the cell with $5 \mathrm{mM}$ $\mathrm{Mg}\left(\mathrm{BH}_{4}\right)_{2}$ in various cycles. (c,d) Cycling performance of the cells and the respective CE. The inset of (c) shows the capacity change upon extended cycling. All cells were tested with a cutoff voltage of $0.5-2.5 \mathrm{~V}$ at $50 \mathrm{~mA} \mathrm{~g}^{-1}$.

Figure 5 displays the XPS detailed spectra in the Mg 2p, F $1 \mathrm{~s}$, and $\mathrm{O} 1 \mathrm{~s}$ regions of the electrodes after cycling in the electrolyte without or with additives. In the $\mathrm{Mg} 2 \mathrm{p}$ spectra, there are two peaks detected at 49.5 and $51 \mathrm{eV}$, which correspond to metallic $\mathrm{Mg}^{0}$ and oxidized $\mathrm{Mg}^{2+}$ species $(\mathrm{MgO}$, $\mathrm{MgF}_{2}$, and so forth), respectively. ${ }^{30,31}$ Comparison of the intensities of these two features demonstrates that $\mathrm{Mg}^{2+}$ species were dominant on the surface, indicating that $\mathrm{MgO}$ and $\mathrm{MgF}_{2}$ are major components of the SEI. Since bulk MgO and $\mathrm{MgF}_{2}$ suffer from a high $\mathrm{Mg}^{2+}$ migration energy barrier, the interphase layer is likely to have a porous structure that allows $\mathrm{Mg}$ transport. A similar chemically inert interphase was also reported elsewhere for reversible $\mathrm{Mg}^{21}$ and Ca plating. ${ }^{32,33}$ Upon sputtering, the peak of metallic $\mathrm{Mg}^{0}$ gained successively in intensity and became the dominating signal in the $\mathrm{Mg} 2 \mathrm{p}$ region after removal of $\sim 30 \mathrm{~nm}$ of the surface layer. A slight shift of the peak related to the oxidized species can be noted upon sputtering, which is most presumably related to changes in the chemical environment of these species. The presence of $\mathrm{MgO}$ and $\mathrm{MgF}_{2}$ is corroborated by the detection of the corresponding peaks of these species in the $\mathrm{O} 1 \mathrm{~s}$ ( $\mathrm{MgO}$ : $\sim 530.5 \mathrm{eV})$ and $\mathrm{F} 1 \mathrm{~s}\left(\mathrm{MgF}_{2}: \sim 685.5 \mathrm{eV}\right)$ detailed spectra. Furthermore, for the topmost surface (measurements before sputtering), the detailed spectra in these two regions also reveal the presence of other species such as $-\mathrm{CF}_{x}$ (F 1s peak at $\sim 690 \mathrm{eV})$ and $-\mathrm{CO}_{x}(\mathrm{O} 1 \mathrm{~s}$ peak at $\sim 532.5 \mathrm{eV})$ groups in the SEI layer. ${ }^{34}$ These species are most probably coming from side reactions (e.g., decomposition of the electrolyte) along with $\mathrm{Mg}$ plating/stripping and/or the electrolyte residues. In addition, B 1s signals were only detected in the spectra of the topmost surface (Figure S6), which could be due to some electrolyte residues rather than the SEI layer itself.
Comparison of the spectra in Figure $5 \mathrm{a}, \mathrm{b}$ leads to the conclusion that SEI components, such as $\mathrm{MgO}, \mathrm{MgF}_{2}$, and species that contain $-\mathrm{CF}_{x}$ and $-\mathrm{CO}_{x}$ groups, have a notably higher concentration in the surface layer of the $\mathrm{Mg}$ anode cycled with the additive-containing electrolyte. This result is consistent with the quantitative analysis (Figure S5) that SEI formation is easier in the presence of $\mathrm{Mg}\left(\mathrm{BH}_{4}\right)_{2}$. Correlating it with the $\mathrm{Mg}$ plating/stripping data, the XPS results also demonstrate the beneficial effect of $\mathrm{Mg}\left(\mathrm{BH}_{4}\right)_{2}$ on building an SEI layer which allows the anode-electrolyte charge transfer and thereby results in a smaller overpotential. Moreover, the SEI layer ensures chemically and electrochemically stable interfaces which promise a long-term cycling stability at the anode side.

2.3. Full-Cell Performance with the $\operatorname{Mg}\left[\mathrm{B}(\mathrm{hfip})_{4}\right]_{2} /$ DME-Based Electrolyte. Finally, the additive effect on the full-cell performance was investigated in $\mathrm{Mo}_{6} \mathrm{~S}_{8}-\mathrm{Mg}$ cells. Compared to the neat electrolyte-based cell, a significant improvement of the initial capacity was found with the additive-containing electrolytes, as shown in the voltage profiles in Figure 6a. After adding $5 \mathrm{mM} \mathrm{Mg}\left(\mathrm{BH}_{4}\right)_{2}$, the cell provided a discharge capacity of $96 \mathrm{~mA} \mathrm{~h} \mathrm{~g}^{-1}$ in the first cycle. In the following charge process, a distinct voltage plateau appeared at $1.25 \mathrm{~V}$, presumably corresponding to $\mathrm{Mg}$ deintercalation from the outer-ring sites. The plateau was followed by a charging slope, which could originate from the extraction of $\mathrm{Mg}$ from the inner-ring sites. ${ }^{35}$ Increasing the additive concentration to $7.5 \mathrm{mM}$ did not improve the redox reactions except for a slight extension of the charge plateau.

Figure $6 \mathrm{~b}$ shows the voltage profiles of the cell with $5 \mathrm{mM}$ $\mathrm{Mg}\left(\mathrm{BH}_{4}\right)_{2}$. Benefiting from fast anode conditioning and SEI formation, the higher discharge capacity in the first cycle ensured sufficient $\mathrm{Mg}^{2+}$ ions inserted into the $\mathrm{Mo}_{6} \mathrm{~S}_{8}$ cathode. 

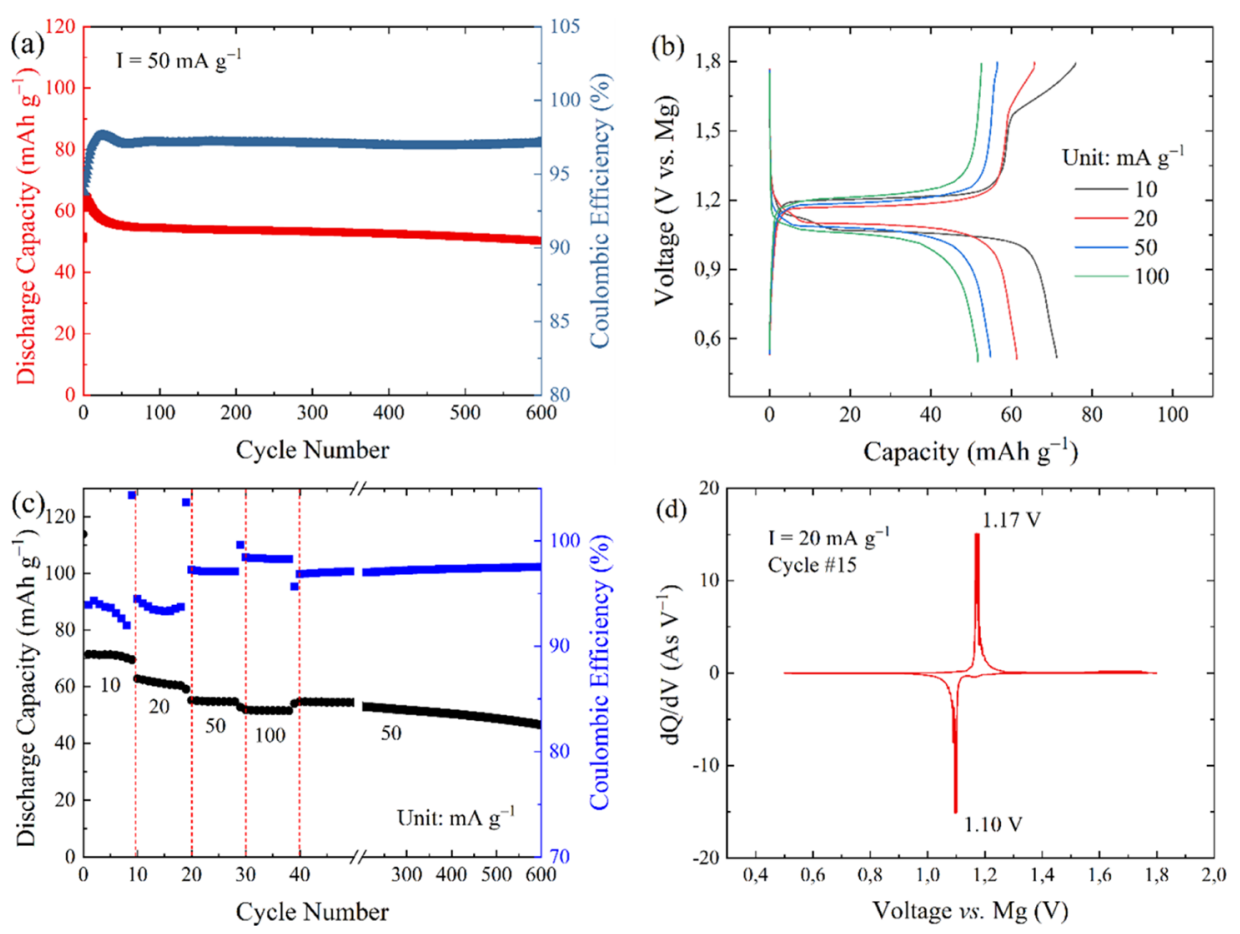

Figure 7. Full-cell test with the electrolyte containing $5 \mathrm{mM} \mathrm{Mg}\left(\mathrm{BH}_{4}\right)_{2}$ in the voltage range of $0.5-1.8 \mathrm{~V}$ : (a) cycling at $50 \mathrm{~mA} \mathrm{~g}{ }^{-1}$; (b) typical voltage profiles at different current densities; (c) rate capability; and (d) $\mathrm{d} Q / \mathrm{d} V$ plot of the 15 th cycle from the rate capability test.

Although the $\mathrm{Mg}^{2+}$ ions that occupied the inner rings of the $\mathrm{Mo}_{6} \mathrm{~S}_{8}$ cages suffered from the kinetic issue, ${ }^{27}$ their occupation boosted further $\mathrm{Mg}^{2+}$ ion mobility. Therefore, the cell delivered a stable capacity of $\sim 70 \mathrm{~mA} \mathrm{~h} \mathrm{~g}{ }^{-1}$ from the second cycle onward (Figure 6c), with a high CE (Figure 6d). In contrast, the activation process with the neat electrolyte (Figure S7) lasts for 20 cycles with a simultaneous increase in the cell capacity to $68 \mathrm{~mA} \mathrm{~h} \mathrm{~g}{ }^{-1}$ and a gradual decrease in the voltage hysteresis. This is accompanied by a reduction of the CE from $>250 \%$ to a stable value of $\sim 97 \%$, due to the slow occupation of the inner-ring site of $\mathrm{Mo}_{6} \mathrm{~S}_{8}$ in the activation cycles. Once the inner-ring sites were fully occupied, the activation process finished. From then on, both the capacity and $\mathrm{CE}$ stabilized. It may be noted that the addition of $\mathrm{Mg}\left(\mathrm{BH}_{4}\right)_{2}$ did not lead to a notable negative effect on the long-term cycling performance, as evidenced in the inset of Figure 6c. However, the poor chemical stability of $\mathrm{Mg}\left(\mathrm{BH}_{4}\right)_{2}$ needs to be considered for its application as an electrolyte additive in full-cell studies.

Nevertheless, it was noticed that the CE of the full-cell measurement with $5 \mathrm{mM} \mathrm{Mg}\left(\mathrm{BH}_{4}\right)_{2}$ shows a decrease to $90 \%$ during the first 20 cycles followed by an increase to $97 \%$ after 50 cycles (see Figure S8). The fluctuation of CE could be due to the decomposition of $\mathrm{BH}_{4}{ }^{-}$at high voltages, which could be suppressed by narrowing the cutoff range. In fact, by lowering the upper cutoff voltage to $1.8 \mathrm{~V}$, a cell with the same configuration provides a higher CE of $>94 \%$ for the initial 50 cycles. As shown in Figure 7a, it also exhibits a stable discharge capacity of $\sim 50 \mathrm{~mA} \mathrm{~h} \mathrm{~g}^{-1}$ at a current density of $50 \mathrm{~mA} \mathrm{~g}^{-1}$ for up to 600 cycles, demonstrating a superior cycling stability. Higher capacities of 71 and $61 \mathrm{~mA} \mathrm{~h} \mathrm{~g}^{-1}$ were obtained at lower current rates of 10 and $20 \mathrm{~mA} \mathrm{~g}^{-1}$, respectively (Figure $7 \mathrm{~b})$. Meanwhile, the discharge plateau at $1.2 \mathrm{~V}$ only appears at low current density, confirming the kinetics issue for $\mathrm{Mg}$ storage at the $\mathrm{Mo}_{6} \mathrm{~S}_{8}$ inner rings. For comparison, ion mobility in the outer rings is high enough even for a dis-/charge at a high current of $100 \mathrm{~mA} \mathrm{~g}^{-1}(\sim 0.8 \mathrm{C})$, and the cell delivers a capacity of $52 \mathrm{~mA} \mathrm{~h} \mathrm{~g}$. Good capacity retention shown in Figure $7 \mathrm{c}$ indicates an excellent rate capability. In addition, the cell shows a low voltage hysteresis. In the $\mathrm{d} Q / \mathrm{d} V$ plot (Figure $7 \mathrm{~d}$ ), the overpotential for de-/magnesiation was only $0.07 \mathrm{~V}$ at $20 \mathrm{~mA} \mathrm{~g}^{-1}$, indicating a high energy efficiency.

\section{CONCLUSIONS}

In summary, we have demonstrated a reversible $\mathrm{Mg}$ intercalation into Chevrel phase $\mathrm{Mo}_{6} \mathrm{~S}_{8}$ from the noncorrosive electrolyte $\mathrm{Mg}\left[\mathrm{B}(\mathrm{hfip})_{4}\right]_{2} / \mathrm{DME}$. To reach stable and reversible $\mathrm{Mg}$ storage, the respective cell requires activation cycles, during which a stable anode-electrolyte interface was established. It was found that $\mathrm{BH}_{4}{ }^{-}$can boost the activation process by efficiently removing the native oxide layer on the $\mathrm{Mg}$ surface and promoting the SEI formation. With only $5 \mathrm{mM}$ $\mathrm{Mg}\left(\mathrm{BH}_{4}\right)_{2}$ additive to the $\left.\mathrm{Mg}[\mathrm{B} \text { (hfip })_{4}\right]_{2} / \mathrm{DME}$ electrolyte, a lower charge transfer resistance and reduced overpotentials in the first cycles can be achieved. The improvement at the anode side in turn helps initial $\mathrm{Mg}^{2+}$ insertion into the $\mathrm{Mo}_{6} \mathrm{~S}_{8}$ cathode, resulting in a conditioning-free charge-discharge process. By combining the $\mathrm{Mo}_{6} \mathrm{~S}_{8}$ cathode and the additivecontaining electrolyte, the cell exhibits an excellent cycling stability for up to 600 cycles with a superior rate capability and a low voltage hysteresis. The current study points out the significant role of the electrode-electrolyte interfaces in the Mg-based chemistry. It also highlights the facile strategy by applying functional additives for further optimizing the simplesalt electrolyte systems.

\section{ASSOCIATED CONTENT}

\section{Supporting Information}

The Supporting Information is available free of charge at https://pubs.acs.org/doi/10.1021/acsami.1c08476. 
Materials and methods, additional electrochemical data, XPS B 1s spectra, and elemental content determined by XPS (PDF)

\section{AUTHOR INFORMATION}

\section{Corresponding Authors}

Zhenyou Li - Helmholtz Institute Ulm (HIU)

Electrochemical Energy Storage, D-89081 Ulm, Germany; ○ orcid.org/0000-0001-9624-2124; Email: zhenyou.li@ kit.edu

Zhirong Zhao-Karger - Helmholtz Institute Ulm (HIU) Electrochemical Energy Storage, D-89081 Ulm, Germany; Institute of Nanotechnology (INT), Karlsruhe Institute of Technology (KIT), D-76021 Karlsruhe, Germany; ○ orcid.org/0000-0002-7233-9818; Email: zhirong.zhaokarger@kit.edu

\section{Authors}

Thomas Diemant - Helmholtz Institute Ulm (HIU) Electrochemical Energy Storage, D-89081 Ulm, Germany

Zhen Meng - Helmholtz Institute Ulm (HIU) Electrochemical Energy Storage, D-89081 Ulm, Germany; (1) orcid.org/0000-0001-5756-9159

Yanlei Xiu - Helmholtz Institute Ulm (HIU) Electrochemical Energy Storage, D-89081 Ulm, Germany

Adam Reupert - Helmholtz Institute Ulm (HIU) Electrochemical Energy Storage, D-89081 Ulm, Germany

Liping Wang - Helmholtz Institute Ulm (HIU) Electrochemical Energy Storage, D-89081 Ulm, Germany; (ㄱ) orcid.org/0000-0002-4113-2208

Maximilian Fichtner - Helmholtz Institute Ulm (HIU) Electrochemical Energy Storage, D-89081 Ulm, Germany; Institute of Nanotechnology (INT), Karlsruhe Institute of Technology (KIT), D-76021 Karlsruhe, Germany

Complete contact information is available at: https://pubs.acs.org/10.1021/acsami.1c08476

\section{Author Contributions}

The manuscript was written with contributions of all authors. All authors have given approval to the final version of the manuscript.

\section{Notes}

The authors declare no competing financial interest. All experimental data that support the findings of this study are readily available upon reasonable request from the corresponding authors.

\section{ACKNOWLEDGMENTS}

The authors acknowledge the funding from Bundesministerium furr Bildung und Forschung (BMBF) of Germany via the "MagSiMal" project (03XP0208) and from the European Union's Horizon 2020 research and innovation programme under grant agreement no. 824066 via the "E-MAGIC" project. This work contributes to the research performed at CELEST (Center for Electrochemical Energy Storage Ulm-Karlsruhe) and was partly funded by the German Research Foundation (DFG) under Project ID 390874152 (POLiS Cluster of Excellence).

\section{REFERENCES}

(1) Jäckle, M.; Helmbrecht, K.; Smits, M.; Stottmeister, D.; Groß, A. Self-diffusion barriers: possible descriptors for dendrite growth in batteries? Energy Environ. Sci. 2018, 11, 3400-3407.

(2) Canepa, P.; Sai Gautam, G.; Hannah, D. C.; Malik, R.; Liu, M.; Gallagher, K. G.; Persson, K. A.; Ceder, G. Odyssey of Multivalent Cathode Materials: Open Questions and Future Challenges. Chem. Rev. 2017, 117, 4287-4341.

(3) Aurbach, D.; Lu, Z.; Schechter, A.; Gofer, Y.; Gizbar, H.; Turgeman, R.; Cohen, Y.; Moshkovich, M.; Levi, E. Prototype systems for rechargeable magnesium batteries. Nature 2000, 407, 724-727.

(4) Muldoon, J.; Bucur, C. B.; Gregory, T. Quest for Nonaqueous Multivalent Secondary Batteries: Magnesium and Beyond. Chem. Rev. 2014, 114, 11683-11720.

(5) Mohtadi, R.; Mizuno, F. Magnesium batteries: Current state of the art, issues and future perspectives. Beilstein J. Nanotechnol. 2014, 5, $1291-1311$

(6) Gregory, T. D.; Hoffman, R. J.; Winterton, R. C. Nonaqueous Electrochemistry of Magnesium: Applications to Energy Storage. J. Electrochem. Soc. 1990, 137, 775-780.

(7) Rajput, N. N.; Seguin, T. J.; Wood, B. M.; Qu, X.; Persson, K. A. Elucidating Solvation Structures for Rational Design of Multivalent Electrolytes-A Review. Top. Curr. Chem. 2018, 376, 19.

(8) Yu, Y.; Baskin, A.; Valero-Vidal, C.; Hahn, N. T.; Liu, Q.; Zavadil, K. R.; Eichhorn, B. W.; Prendergast, D.; Crumlin, E. J. Instability at the Electrode/Electrolyte Interface Induced by Hard Cation Chelation and Nucleophilic Attack. Chem. Mater. 2017, 29, 8504-8512.

(9) Mohtadi, R.; Tutusaus, O.; Arthur, T. S.; Zhao-Karger, Z.; Fichtner, M. The metamorphosis of rechargeable magnesium batteries. Joule 2021, 5, 581-617.

(10) Connell, J. G.; Zorko, M.; Agarwal, G.; Yang, M.; Liao, C.; Assary, R. S.; Strmcnik, D.; Markovic, N. M. Anion Association Strength as a Unifying Descriptor for the Reversibility of Divalent Metal Deposition in Nonaqueous Electrolytes. ACS Appl. Mater. Interfaces 2020, 12, 36137-36147.

(11) He, S.; Nielson, K. V.; Luo, J.; Liu, T. L. Recent advances on $\mathrm{MgCl} 2$ based electrolytes for rechargeable $\mathrm{Mg}$ batteries. Energy Storage Mater. 2017, 8, 184-188.

(12) Tutusaus, O.; Mohtadi, R.; Arthur, T. S.; Mizuno, F.; Nelson, E. G.; Sevryugina, Y. V. An Efficient Halogen-Free Electrolyte for Use in Rechargeable Magnesium Batteries. Angew. Chem., Int. Ed. 2015, 54, 7900-7904.

(13) Attias, R.; Salama, M.; Hirsch, B.; Goffer, Y.; Aurbach, D. Anode-Electrolyte Interfaces in Secondary Magnesium Batteries. Joule 2019, 3, 27-52.

(14) Kim, S. S.; See, K. A. Activating Magnesium Electrolytes through Chemical Generation of Free Chloride and Removal of Trace Water. ACS Appl. Mater. Interfaces 2021, 13, 671-680.

(15) Zhao-Karger, Z.; Gil Bardaji, M. E.; Fuhr, O.; Fichtner, M. A new class of non-corrosive, highly efficient electrolytes for rechargeable magnesium batteries. J. Mater. Chem. A 2017, 5, 10815-10820.

(16) Zhang, Z.; Cui, Z.; Qiao, L.; Guan, J.; Xu, H.; Wang, X.; Hu, P.; Du, H.; Li, S.; Zhou, X.; Dong, S.; Liu, Z.; Cui, G.; Chen, L. Novel Design Concepts of Efficient Mg-Ion Electrolytes toward HighPerformance Magnesium-Selenium and Magnesium-Sulfur Batteries. Adv. Energy Mater. 2017, 7, 1602055.

(17) Luo, J.; Bi, Y.; Zhang, L.; Zhang, X.; Liu, T. L. A Stable, NonCorrosive Perfluorinated Pinacolatoborate $\mathrm{Mg}$ Electrolyte for Rechargeable Mg Batteries. Angew. Chem., Int. Ed. 2019, 58, 69676971.

(18) Tutusaus, O.; Mohtadi, R.; Singh, N.; Arthur, T. S.; Mizuno, F. Study of Electrochemical Phenomena Observed at the Mg Metal/ Electrolyte Interface. ACS Energy Lett. 2017, 2, 224-229.

(19) Zhao-Karger, Z.; Liu, R.; Dai, W.; Li, Z.; Diemant, T.; Vinayan, B. P.; Bonatto Minella, C.; Yu, X.; Manthiram, A.; Behm, R. J.; Ruben, M.; Fichtner, M. Toward Highly Reversible Magnesium-Sulfur 
Batteries with Efficient and Practical $\mathrm{Mg}[\mathrm{B}$ (hfip)4]2 Electrolyte. ACS Energy Lett. 2018, 3, 2005-2013.

(20) Meng, Z.; Foix, D.; Brun, N.; Dedryvère, R.; Stievano, L.; Morcrette, M.; Berthelot, R. Alloys to Replace Mg Anodes in Efficient and Practical Mg-Ion/Sulfur Batteries. ACS Energy Lett. 2019, 4, 2040-2044.

(21) Li, B.; Masse, R.; Liu, C.; Hu, Y.; Li, W.; Zhang, G.; Cao, G. Kinetic surface control for improved magnesium-electrolyte interfaces for magnesium ion batteries. Energy Storage Mater. 2019, 22, 96-104.

(22) Lv, R.; Guan, X.; Zhang, J.; Xia, Y.; Luo, J. Enabling Mg metal anodes rechargeable in conventional electrolytes by fast ionic transport interphase. Natl. Sci. Rev. 2020, 7, 333-341.

(23) Sa, N.; Pan, B.; Saha-Shah, A.; Hubaud, A. A.; Vaughey, J. T.; Baker, L. A.; Liao, C.; Burrell, A. K. Role of Chloride for a Simple, Non-Grignard $\mathrm{Mg}$ Electrolyte in Ether-Based Solvents. ACS Appl. Mater. Interfaces 2016, 8, 16002-16008.

(24) Li, Z.; Vinayan, B. P.; Jankowski, P.; Njel, C.; Roy, A.; Vegge, T.; Maibach, J.; Lastra, J. M. G.; Fichtner, M.; Zhao-Karger, Z. MultiElectron Reactions Enabled by Anion-Based Redox Chemistry for High-Energy Multivalent Rechargeable Batteries. Angew. Chem., Int. Ed. 2020, 59, 11483-11490.

(25) Li, Z.; Mu, X.; Zhao-Karger, Z.; Diemant, T.; Behm, R. J.; Kübel, C.; Fichtner, M. Fast kinetics of multivalent intercalation chemistry enabled by solvated magnesium-ions into self-established metallic layered materials. Nat. Commun. 2018, 9, 5115.

(26) Levi, E.; Gershinsky, G.; Aurbach, D.; Isnard, O.; Ceder, G. New Insight on the Unusually High Ionic Mobility in Chevrel Phases. Chem. Mater. 2009, 21, 1390-1399.

(27) Levi, E.; Lancry, E.; Mitelman, A.; Aurbach, D.; Ceder, G.; Morgan, D.; Isnard, O. Phase Diagram of Mg Insertion into Chevrel Phases, MgxMo6T8 $(\mathrm{T}=\mathrm{S}, \mathrm{Se}) .1$. Crystal Structure of the Sulfides. Chem. Mater. 2006, 18, 5492-5503.

(28) Mohtadi, R.; Matsui, M.; Arthur, T. S.; Hwang, S.-J. Magnesium Borohydride: From Hydrogen Storage to Magnesium Battery. Angew. Chem., Int. Ed. 2012, 51, 9780-9783.

(29) Wang, X.; Yasukawa, E.; Mori, S. Inhibition of anodic corrosion of aluminum cathode current collector on recharging in lithium imide electrolytes. Electrochim. Acta 2000, 45, 2677-2684.

(30) Yoo, H. D.; Han, S.-D.; Bolotin, I. L.; Nolis, G. M.; Bayliss, R. D.; Burrell, A. K.; Vaughey, J. T.; Cabana, J. Degradation Mechanisms of Magnesium Metal Anodes in Electrolytes Based on (CF3SO2)2Nat High Current Densities. Langmuir 2017, 33, 9398-9406.

(31) Kang, S.-J.; Kim, H.; Hwang, S.; Jo, M.; Jang, M.; Park, C.; Hong, S.-T.; Lee, H. Electrolyte Additive Enabling Conditioning-Free Electrolytes for Magnesium Batteries. ACS Appl. Mater. Interfaces 2019, 11, 517-524.

(32) Wang, D.; Gao, X.; Chen, Y.; Jin, L.; Kuss, C.; Bruce, P. G. Plating and stripping calcium in an organic electrolyte. Nat. Mater. 2018, 17, 16-20.

(33) Li, Z.; Fuhr, O.; Fichtner, M.; Zhao-Karger, Z. Towards stable and efficient electrolytes for room-temperature rechargeable calcium batteries. Energy Environ. Sci. 2019, 12, 3496-3501.

(34) Bhaghavathi Parambath, V.; Zhao-Karger, Z.; Diemant, T.; Jäckle, M.; Li, Z.; Scherer, T.; Gross, A.; Behm, R. J.; Fichtner, M. Investigation on the formation of $\mathrm{Mg}$ metal anode/electrolyte interfaces in $\mathrm{Mg} / \mathrm{S}$ batteries with electrolyte additives. J. Mater. Chem. A 2020, 8, 22998-23010.

(35) Richard, J.; Benayad, A.; Colin, J.-F.; Martinet, S. Charge Transfer Mechanism into the Chevrel Phase Mo6S8 during $\mathrm{Mg}$ Intercalation. J. Phys. Chem. C 2017, 121, 17096-17103. 